INOBIS: Jurnal Inovasi Bisnis dan Manajemen Indonesia

Volume 1, Nomor 2, Maret 2018

Yonatan Widiyanto, Febriansyah

\title{
Pengaruh Kesadaran Merek dan Citra Merek Terhadap Pembentukan Kesetiaan Merek (Studi Pada Pengguna Aplikasi Line Today)
}

\author{
Yonatan Widiyanto ${ }^{1)}$ Febriansyah $^{2)}$ \\ ${ }^{1)}$ Manajemen, Fakultas Bisnis Institut Teknologi dan Bisnis Kalbis \\ Jl. Pulo Mas Selatan Kav. 22, RT. 4 / RW. 9, Kayu Putih, Pulo Gadung, Jakarta Timur, 13210 \\ Email: yonathan.widiyanto1@gmail.com \\ ${ }^{2)}$ Manajemen, Fakultas Bisnis Institut Teknologi dan Bisnis Kalbis \\ J1. Pulo Mas Selatan Kav. 22, RT. 4 / RW. 9, Kayu Putih, Pulo Gadung, Jakarta Timur, 13210 \\ Email:febriansyah@kalbis.ac.id
}

\begin{abstract}
Abstrak
Penelitian ini bertujuan untuk mengetahui apakah ada pengaruh kesadaran merek dan citra merek terhadap pembentukan kesetiaan merek studi pada pengguna aplikasi Line Today di kampus Kalbis Institut Jakarta. Penelitian ini menggunakan metode kuantitatif. Data dikumpulkan dengan mengunakan teknik penyebaran kuesioner. Sampel untuk penelitian ini adalah pengguna aplikasi line today di kampus kalbis Institut jakarta dengan jumlah sampel sebanyak 347 sampel. Metode kuantitatif meliputi uji validitas dan reliabilitas, uji asumsi klasik, pengujian hipotesis melalui uji f, uji t dan koefisien determinasi. Dalam teknik analisis data yang digunakan adalah analisis regresi linier berganda. Teknik pengujian dengan mengunakan bantuan sistem SPSS 19. Hasil temuan penelitian ini menunjukkan bahwa variabel bebas yaitu kesadaran merek (X1) dan citra merek (X2) secara parsial masing-masing variabel berpengarih signifikan terhadap pembentukan kesetiaan merek (Y), dan selanjutnya variabel kesadaran merek (X1) dan citra merek (X2) secara simultan atau secara bersamasama berpengaruh segnifikan terhadap pembentukan kesetiaan merek sebagai variabel terikat (Y).
\end{abstract}

Kata kunci: Kesadaran merek, citra merek, kesetiaan merek, Line Today.

\section{Pendahuluan}

Potensi pasar di Indonesia khususnya dibidang aplikasi mempunyai banyak peluang, dan beberapa aplikasi besar sudah menempatkan segmentasi masing-masing di tanah air Indonesia. Seperti aplikasi Social Network dan Messenger Chat App. Dengan banyaknya aplikasi yang aktif dan digunakan sesuai kebutuhan tentunya masing-masing aplikasi mempunyai kelemahan dan kelebihan, mempunyai jumlah pesaing yang kuat dan mempunyai kesempatan bersaing dan memperluas jumlah pemakai aplikasi terkait. Aplikasi Line di kembangkan oleh perusahaan Jepang bernama NHN Corporation. Line pertama kali dirilis pada Juni 2011 dan mulanya hanya dapat digunakan pada sistem iOS dan Android. Setelah sukses pada kedua sistem tersebut Line masuk dalam didalam sistem operasi besutan BlackBerry. Lalu pada tahun 2012, Line resmi meluncurkan aplikasi yang dapat digunakan pada perangkat Mac dan Windows. Line melakukan banyak perubahan dalam memajukan bisnis aplikasi ini. 
INOBIS: Jurnal Inovasi Bisnis dan Manajemen Indonesia

Volume 1, Nomor 2, Maret 2018

Yonatan Widiyanto, Febriansyah

Gambar 1.1 Logo aplikasi Line

Dari gambar 1.1 gambar tersebut adalah logo dari aplikasi Line. Saat ini aplikasi Line merupakan istilah popular untuk sarana berkomunikasi. Di era globalisasi, aplikasi Line merupakan sebuah alat komunikasi dan informasi yang sangat diperlukan oleh beberapa kalangan dari kalangan pelajar, orang tua, pekerja, perusahaan, dan pemerintah, kebutuhan akan sebuah informasi mendorong manusia untuk lebih mengerti akan kecanggihan beragam teknologi yang hadir saat ini. adapun kelebihan dari aplikasi Line yaitu memiliki banyak manfaat bagi penggunanya, memlalui fitur-fitur yang di kembangkan sebagai berikut:

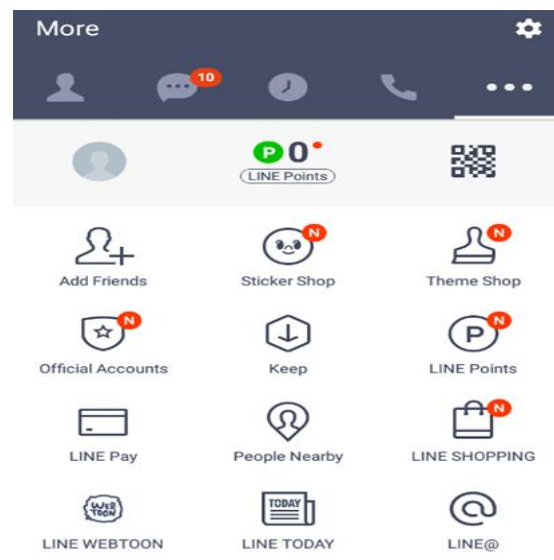

Gambar 1.2 Fitur-Fitur Line

Manfaat fitur-fitur Line bagi penggunanya, antar lain sebagai sarana untuk menambah jaringan petemanan, official Accounts bagi perusahaan, penyampaian pesan, Line Today membaca berita dan gosip, Line game, Line@ untuk berbisnis, Line webtoon untuk membaca komik dan diskusi di sesama pengguna, aplikasi Line,

Line Today adalah suatu fitur media sosial yang merekat di dalam aplikasi Line dengan jenis konten berita-berita online dan gosip-gosip terhangat. Di era perkembangan teknologi ini. Line Today dirilis pada tanggal 3 Juli 2012 sebagai fitur ungulan aplikasi Line, masyarakat dimanjakan dengan cangihnya teknologi aplikasi yang merambah ke dunia media komunikasi berbasis digital ini.

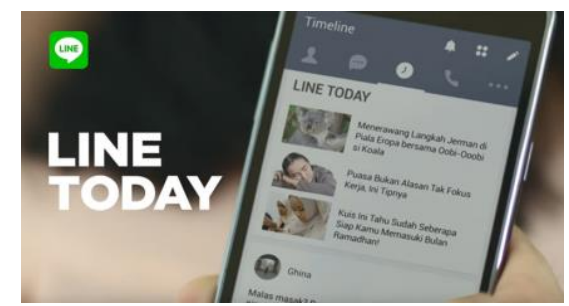

Gambar 1.3 Tampilan Fitur Line Today 
INOBIS: Jurnal Inovasi Bisnis dan Manajemen Indonesia

Volume 1, Nomor 2, Maret 2018

Yonatan Widiyanto, Febriansyah

Penjelasan dari gambar 1.3 diatas adalah isi tampilan portal Line Today, Fitur ini menjadi fenomena baru Di Dalam golongan generasi milenial, dengan fitur ini pengguna Line menjadi sangat mudah untuk membaca berita tanpa keluar dari aplikasi Line, dan menariknya manfaat fitur Line Today menghubungkan berbagai portal berita lainya yang bisa pengguna akses seperti Liputan6.com,TrimbunNews,Kompas.com, Repoblika.com, viva.com dan lain lain. Line Today memiliki bermacam-macam informasi seperti Intertaiment, News, Showbiz, Sci-Tech, Life, Sports, Intermezzo, Webtoon.

Adapun aplikasi sosial media yang merambah kepada dunia media komunikasi dan informasi berbasis digital ini tidak hanya fitur Line Today, melaikan ada jenis lain yang mengusung berita berita online. Berikut adalah data yang peneliti pelajari.

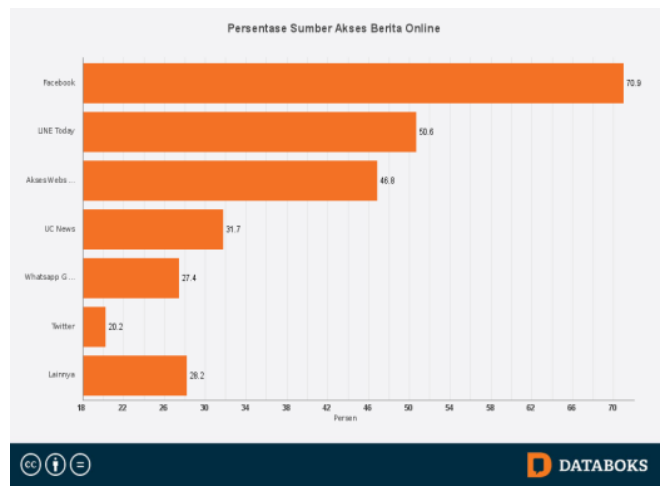

\section{Gambar 1.4 Presentasi pembaca berita online melalui sosial media}

Dari Gambar 1.4 di atas menjelaskan bahwa Line Today memiliki kurang lebihnya 7 kompetitor, Line Today memiliki presentase sebesar 50,6\% dari data yang mengakses berita online, dari data di atas Line Today menempati urutan kedua setelah facebook yang memiliki jumlah presentase cukup banyak yaitu 70,9\%.

Survei tentang media online di Indonesia yang dilakukan oleh DailySocial.id menunjukkan bahwa hampir tujuh puluh pesen (70\% )pembaca berita online meneruskan dan membagikan berita tersebut di berbagai media sosial miliknya. Hanya 30,83\% yang mengaku tidak membagikan berita tersebut di media sosial. Facebook masih menjadi media sosial yang paling populer untuk membagikan berita. Berikut adalah data yang peneliti pejalari dari presentase pembaca berita online yang membagikan berita berdasarkan media.

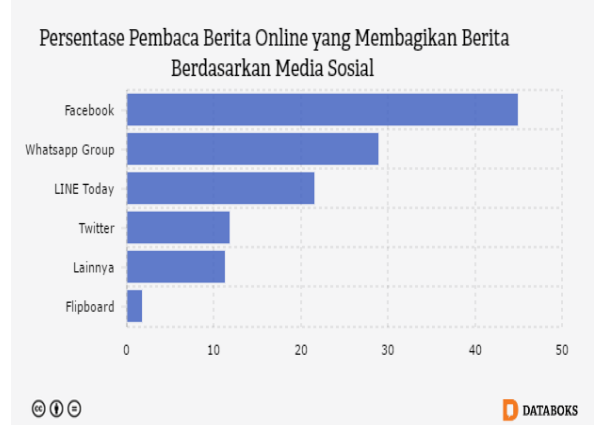

Gambar 1.5 Presentase pembaca berita online yang membagikan melalui media sosial 
INOBIS: Jurnal Inovasi Bisnis dan Manajemen Indonesia

Volume 1, Nomor 2, Maret 2018

Yonatan Widiyanto, Febriansyah

Dari gambar 1.5 menjelaskan $44.86 \%$ pengguna aplikasi besutan Mark Zuckerberg ini yaitu facebook meneruskan berita online yang dibaca. Selanjutnya, 28,85 \% juga membagikan berita yang dibaca melalui aplikasi Whatsapp ke dalam group yang mereka ikuti, kemudian Line Today menempati urutan ke tiga dengan presentase 21,54\%. Data selanjutnya menjelaskan bagaimana dalam ranah subuah bisnis media, apakah perusahaan Massager Chat App yang menjadi pemain baru di ranah media informsi bisa lebih dominan digunakan dibandingkan perusahaan aplikasi media online. seperti Detik.com, Liputan 6.com, Trimbun News dan lain-lain yang notabenya adalah pemain media konvensional sejak jaman media cetak. Untuk mencari informasi, generasi milenial lebih menggunakan sosial media sebagai platform mencari informasi. Hal tersebut ditunjukan oleh data sebagai berikut

$\begin{array}{lccccc}\text { Keterangan } & 18- & 25- & 35- & 45- & >55 \\ & 24 & 34 & 44 & 54 & \\ \begin{array}{l}\text { Online/Media } \\ \text { Sosial }\end{array} & 66 \% & 57 \% & 49 \% & 38 \% & 27 \% \\ \text { Media Sosial } & 30 \% & 20 \% & 15 \% & 10 \% & 7 \% \\ \text { Radio } & 7 \% & 8 \% & 9 \% & 10 \% & 10 \% \\ \text { Cetak } & 6 \% & 7 \% & 8 \% & 9 \% & 9 \% \\ \text { Televisi } & 24 \% & 30 \% & 38 \% & 49 \% & 53 \%\end{array}$

\section{Gambar 1.6 Pembaca berita online melalui klompok umur}

Dari gambar 1.6 diatas, menunjukan data kategori media online dan media sosial memiliki angka yang lebih besar dibandingkan dengan media konvensional seperti media cetak. Media online seperti Detik.com, Trimbun News, Lipitan6.com, Kompas.com sebagai perusahan media cetak dan merupakan pemain lama, saat ini perusahaan tersebut merambah ke dunia media online dan menempati urutan teratas jika melihat data diatas. Perusahaan Messanger Chat App seperti Line Today yang menjadi pemain baru di ranah media Online dan sosial media menempati urutan ke dua, hal ini menunjukan kesempatan dan peluang untuk pemain baru sepeti Line Today melakukan expansi untuk bisa bersaing lebih di ranah media online

Berdasarkan latar belakang masalah diatas, rumusan masalah yang akan menjadi acuan untuk diteliti adalah sebagai berikut:

1. Seberapa besar pengaruh kesadaran merek berpengaruh terhadap pembentukan kesetiaan merek.

2. Seberapa besar pengaruh citra merek berpengaruh terhadap pembentukan kesetiaan merek.

3. Seberapa besar pengaruh kesadaran merek dan citra merek secara bersama sama atau secara simultan berpengaruh terhadap pembentukan kesetiaan merek

\section{Metode Penelitian}

Menurut Stephen P. Robbins dan Mary Coulter (2010:7) Manajemen melibatkan aktivitas-aktivitas koordinasi dan pengawasan terhadap pekerjaan orang lain, sehingga pekerjaan tersebut dapat diselesaikan secara efisien dan efektif. Menurut Wijayanto (2012:2) 
INOBIS: Jurnal Inovasi Bisnis dan Manajemen Indonesia

Volume 1, Nomor 2, Maret 2018

Yonatan Widiyanto, Febriansyah

Manajemen dikatakan sebagai seni. Sebagai ilustrasi, dalam terapan pengambilan keputusan, keputusan yang diambil sering kali bervariasi meskipun diberikan data dan informasi yang sama. Oleh karena itu, manajemen juga merupakan seni , yaitu seni pengambilan keputusan, seni pengelolaan SDM (sumber daya manusia),seni pengelolaan keuangan dan seni pengelolaan pemasaran, dsb. Terkait dengan keputusan, secara external dapat dibedakan kedalam 2 tipe pengambilan keputusan, yaitu risk taker( pengambilan resiko ) dan risk avoider ( penghindar resiko )

Menurut Fandy Tjiptono dan Gregorius Candra (2012:193). Program pemasaran meliputi tindakan-tindakan pemasaran yang bisa mempengaruhi permintaan terhadap produk atau jasa, di antara mengubah harga, modifiksi kampanye iklan, merancang promosi khusus menetukan saluran distribusi dan sebagainya. Menurut Kotler dan Keller (2008:5) Apa itu pemasaran, inti dari pemasaran (marketing) adalah me ngindetifikasi dan memenuhi kebutuhan manusia dan social. Salah satu definisi yang baik dan singkat dari pemasaran adalah"memenuhi kebutuhan dengan cara yang menguntungkan".America Marketing Association (AMA) menawarkan definisi formal tersebut. Pemasaran adalah suatu fungsi organisasi yang serangkaian proses menciptakan, mengkomunikasikan dan memberikan nilai kepada pelanggan dan untuk mengelolah hubungan pelanggan dengan cara yang menguntungkan organisasi dan pemangku kepentingan. Menurut Wijayanto (2012:279280) Manajemen Pemasaran adalah seni dan ilmu dalam memilih target pasar, meraih, menjaga, dan mengembangkan konsumen melalui pengkreasian, pengkomunikasian dan pengantaran nilai konsumen yang tinggi (superior customer value) berdasarkan definisi diatas jelas bahwa pemasaran lebih luas dari pada penjualan, di mana penjualan hanyala bagian dari pemasaran.

Menurut Kartajaya (2010:60) Merek menjadi suatu hal yang penting dalam sebuah perusahaan, merek bukan hanya sebuah nama atau simbol, tetapi memiliki peran yang jauh lebih besar dari pada itu. Merek bisa menjadi peran sebagai payung representasi produk barang atau jasa yang ditawarkan. Produk atau jasa tanpa merek hanya menjadi sebuah komoditas, tetapi sebaliknya jika produk atau jasa memiliki merek yang kuat merek akan memiliki nilai tinggi bagi pelanggan. Menurut Kotler dan Keller (2008:259) Merek mengedentifikasi sumber atau pembuat produk dan memungkinkan konsumen bisa individual atau organisasi untuk menuntut tanggung jawab atas kinerjanya kepada pabrikan atau distributor tertentu. Konsumen dapat mengevaluasi produk yang sama secara berbeda tergantung pada bagaimana pemerekan produk tersebut. Mereka belajar tentang merek melalui pengalaman masa lalu dengan produk tersebut dan program pemasarannya, menemukan merek mana yang memuaskan kebutuhan mereka dan mana yang tidak. Ketika hidup konsumen menjadi semakin rumit, terburu buru, dan kehabisan waktu, kemampuan dalam sebuah merek untuk menyederhanakan dalam pengambilan keputusan dan mengurangi resiko adalah sesuatu yang berharga. Menurut Fandy Tjiptono dan Gregorius Chandra (2012:236-248) merek merupakan salah satu aset organisasi paling berharga. Bagi produsen, merek berperan penting bagi wahana identifikasi produk atau jasa, bentuk proteksi hukum, signal jaminan kualitas,sarana menciptakan asosiasi dan makna unik (diferensiasi), sarana keungulan kompetitif, dan sumber financial returns.Sementara bagi konsumen, merek berperan krusial bagi identifikasi sumber produk, penepatan tanggung jawab pada produsen atau distributor spesifik, pengaruh resiko, penekan biaya pencarian internal dan external, janji atau ikatan khusus dengan konsumen, alat simbolis yang memproyeksikan citra diri, dan signal kualitas. Menurut Kotler dan Keller (2008:260) Penetapan merek dalam sebuah produk atau jasa, perusahaan memberikan mementum untuk menciptakan merek melalui pemasaran 
INOBIS: Jurnal Inovasi Bisnis dan Manajemen Indonesia

Volume 1, Nomor 2, Maret 2018

Yonatan Widiyanto, Febriansyah

dan kegiatan lainnya.Dalam perseptual yang berakar dalam realita tetapi mencerminkan persepsi dan kebiasan konsumen. Agar strategi penetapan merek berhasil dan nilai merek dapat tercipta, konsumen harus diyakinkan bahwa ada perbedaan berarti diantara merek dalam katagori produk atau jasa (Kotler dan Keller,2008:260). Kevin Lane Keller (2013:142)menyebut terdapat beberapa kriteria didalam pemilihan elemen merek, antara lain:

1. Memorable (Mudah diingat) Merupakan suatu kondisi yang diperlukan dalam membangun citra merek untuk mencapai tingkat kesadaran merek yang tinggi.

2. Meaningful (Memiliki makna) Elemen merek hendaknya memiliki suatu makna, baik dengan konten deskriptif atau persuasif. Deskripsi makna yang terkandung dapat berupa :

a) Informasi umum tentang fungsi dari produk atau layanan

b) Informasi spesifik tentang atribut tertentu dan manfaat merek

3. Likeable (Dapat disukai) Konsumen biasanya akan mencari suatu merek yang dapat menarik perhatiannya, dimana merek tersebut dapat disukai secara visual, verbal, maupun dengan cara lainnya.

4. Transferable(Dapatditransferkn) Elemen dapat ditransferkan merupakan suatu langkahlangkah dimana elemen merek dapat menambah ekuitas merek untuk produk baru atau pasar baru.

5. Adaptable (Mudah beradaptasi) Adanya perubahan nilai-nilai konsumen dan adanya berbagai opini menyebabkan merek harus memiliki adanya elemen yang dapat berbaur dan mudah beradaptasi. Semakin mudah elemen merek beradaptasi dan fleksibel, semakin mudah pula untuk segera memperbaruinya. contohnya saja logo dan karakter yang dapat diberikan tampilan baru atau desain yang baru untuk membuatnya tampil lebih moderen dan relevan.

6. Protectable (Dapat dilindungi) Elemen merek yang terakhir adalah dapat dilindungi baik dalam hukum maupupun dalam persaingan. Pemasar harus memilih elemen merek yang dapat dilindungi secara hukum dan dengan secara resmi melakukan tahap berikutnya dengan mendaftarkannya pada badan hukum yang tepat dan memiliki merek dagang yang sah.

Kartajaya (2010:64) Mendifinisikan kesadaran merek sebagai kemampuan dari pelanggan potensial untuk mengenali atau mengingat bahwa suatu merek termasuk kedalam kategori produk atau jasa tertentu. Kemampuan pelanggan untuk mengenali atau mengingat merek suatu produk berbeda tergantung tingkat komunikasi merek atau persepsi pelanggan terhadap merek produk yang ditawarkan. Berikut adalah tingakat dari brand awareness:

\section{Unaware of brand}

Pada tahapan ini, pelanggan merasa ragu atau tidak yakin apakah sudah mengenal merek yang disebutkan atau belum. Tingkatan ini yang harus dihindari oleh perusahaan

2. Brand recognition

Pada tahapan ini, pelanggan mampu memahami dan mengindentifikasi merek yang disebutkan

3. Brand recall

Pada tahapan ini, pelanggan mampu mengingat merek tanpa diberikan stimulus; 
INOBIS: Jurnal Inovasi Bisnis dan Manajemen Indonesia

Volume 1, Nomor 2, Maret 2018

Yonatan Widiyanto, Febriansyah

\section{Top of mind}

Pada tahap ini, pelanggan mengingat merek sebagai yang pertama kali muncul di pikiran saat berbicara mengenai kategori produk tertentu.

Kesadaran merek dapat didefinisikan sebagai kemampuan pembeli potensial untuk mengenali (recognize) atau mengingat kembali (recall) suatu merek sebagai bagian dari suatu kategori produk Durianto. Menurut Humdiana (2005), kesadaran merek adalah kesanggupan seorang pembeli untuk mengenali atau mengingat kembali bahwa suatu merek merupakan bagian dari kategori produk tertentu. Humdiana (2005) juga berpendapat bahwa kesadaran merek mempunyai empat tingkatan yang berbeda yaitu Topof mind, Brand Recall, Brand Recognition, dan Unaware of brand.

Citra merek adalah variabel yang penting dalam pengetahuan untuk mempelajari tentang merek. Menurut Kotler (2006:266) citra merek adalah penglihatan dan kepercayaan yang terpendam di benak konsumen, sebagai cerminan asosiasi yang tertahan di ingatan konsumen. Citra merek dibentuk melalui kepuasan konsumen, penjualan dengan sendirinya diperoleh melalui kepuasan konsumen, sebab konsumen yang puas selain akan kembali membeli, juga akan mengajak calon pembeli lainnya (Aaker dalam Farid Yuniar Nugroho, 2011:10).

Menurut Schiffman dan Kanuk (2009), loyalitas merek adalah preferensi konsumen secara konsisten untuk melakukan pembelian pada merek yang sama pada produk yang spesifik atau kategori pelayanan tertentu. Loyalitas merek adalah sebuah komitmen yang kuat dalam berlangganan atau membeli suatu merek secara konsisten di masa yang akan datang. Rangkuti (2009) menjelaskan bahwa loyalitas merek dapat diukur melalui:

1. Behavior measures Suatu cara langsung untuk menentukan loyalitas terutama untuk habitual behavior (perilaku kebiasaan) adalah dengan memperhitungkan pola pembelian aktual.

2. Measuring switch cost Pengukuran pada variabel ini dapat mengidentifiksikan loyalitas pelanggan dalam suatu merek. Pada umumnya jika biaya untuk mengganti merek sangat mahal, pelanggan akan enggan untuk berganti merek sehingga laju penyusutan kelompok pelanggan dari waktu ke waktu akan rendah.

3. Measuring satisfaction kepuasan atau ketidakpuasan pelanggan suatu merek merupakan indikator paling penting dalam loyalitas merek. Bila ketidakpuasan pelanggan terhadap suatu merek rendah, maka pada umumnya tidak cukup alasan bagi pelanggan untuk berpindah ke merek lain kecuali bila ada faktor penarik yang cukup kuat.

4. Measuring liking brand Kesukaan terhadap merek, kepecayaan, perasaan hormat atau bersahabat dengan merek membangkitkan kehangatan dan kedekatan dalam perasaan pelanggan. Akan sulit bagi merek lain untuk menarik pelanggan yang berada dalam tahap ini. Ukuran rasa suka tersebut adalah kemauan untuk membayar harga yang lebih mahal untuk mendapatkan produk tersebut.

5. Measuring commitment indikator kunci adalah jumlah interaksi dan komitmen seorang pelanggan terkait dengan produk tersebut. Kesukaan pelanggan akan suatu merek akan mendorong mereka untuk membicarakan merek tersebut kepada orang lain baik dalam taraf menceritakan atau sampai tahap merekomendasikan.

Menurut Jan Jonker, Bartjan dan Sari Wahyuni ( 2011:38 ) Kebanyakan model berfungsi untuk menggambarkan ide-ide, membawa kedepan kunci fenomena sifat dan 
INOBIS: Jurnal Inovasi Bisnis dan Manajemen Indonesia

Volume 1, Nomor 2, Maret 2018

Yonatan Widiyanto, Febriansyah

membantu mengarahkan pola tertentu, tindakan atau bagaimana hal-hal yang terus bersama dalam hubungan intruksi. Pada dasarnya, model ilmiah berasal dari tradisi dimana hubungan kausal sebuah hipotesis digambarkan, dioprasionalkan, kemudian diuji dan diverifikasikan. Penelitian ini memiliki tujuan untuk mengetahui dan memahami analisa pengaruh kesadaran merek dan citra merek terhadap pembentukan kesetiaan merek penguna aplikasi Line Today di kampus Kalbis Institute. Dalam penelitian ini dapat dibuat suatu kerangka pemikiran yang dapat menjadi landasan dalam penulisan ini, yang pada akhirnya akan dapat diketahui variabel mana yang paling berpengaruh dominan dalam penelitian ini.

\section{A. Model Konseptual Penelitian dan Hipotesis}

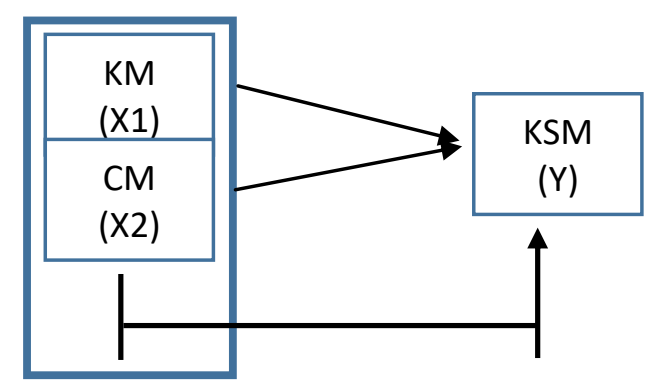

Konseptual model diatas menjelaskan dalam penelitian ini untuk mengetahui gambaran kerangka berfikir penelitian dari variabel kesadaran merek (X1) dan variabel citra merek (X2) terhadap pembentukan kesetiaan merek (Y) secara parsial dan simultan. Secara parsial yang artinya masing - masing variabel yaitu variabel kesadaran merek secara individu mempengaruhi variabel kesetiaan merek, dan variabel citra merek secara individu mempengaruhi variabel kesetiaan merek. Jika secara simultan yaitu variabel kesadaran merek dan variabel citra merek secara bersamaan mempengaruhi variabel kesetiaan merek.

Variabel penelitian yang digunakan dalam penelitian ini adalah :

\section{Variabel Independen}

- $\quad$ Kesadaran merek (X1)

- $\quad$ Citra Merek (X2)

Variabel independen sering disebut sebagai variabel bebas. Variabel bebas adalah variabel yang mempengaruhi atau yang menjadi sebab perubahannya atau timbulnya variabel dependen (Sugiyono 2004:33).

\section{Variabel Dependen}

- $\quad$ Kesetiaan merek

Variabel dependen adalah variabel terikat merupakan variabel yang dipengaruhi atau yang menjadi akibat, karena adanya variabel bebas. (Sugiyono 2004:33)

\section{B . Oprasional Variabel}

Menurut peneliti operasional variabel adalah di mana variabel yang ditetapkan dengan bantuan teori masing-masing variabel, mampu menunjukan definisi untuk sebuah indikator 
INOBIS: Jurnal Inovasi Bisnis dan Manajemen Indonesia

Volume 1, Nomor 2, Maret 2018

Yonatan Widiyanto, Febriansyah

yang akan berdampak kedalam penyataan-pernyataan kuesioner, untuk dibagikan kepada responden.

Definisi operasional variabel merupakan suatu definisi yang diberikan kepada suatu variabel dengan memberi arti atau menspesifikkan kegiatan atau membenarkan suatu operasional yang diperlukan untuk mengukur variabel tersebut(Sugiyono,2004).

\section{Hubungan Antara Variabel Dan Hipotesi}

Menurut Sugiyono (2004:51) Hipotesis merupakan jawaban sementara terhadap rumusan masalah peneliti, dengan bentuk kalimat pertanyaan. kenapa dikatakan sementara, karena jawaban yang diberikan baru berdasarkan pada teori yang relevan, belum berdasarkan pada fakta-fakta yang diperoleh melalui pengumpulan data. Jadi hipotesis juga bisa dinyatakan sebagai jawaban teoritis terhadap rumusan masalah. Jika dilihat dari variabel independen dan dependen dengan teori-teori dan kerangka berfikir yang digunakan dan dikaitakan dari teori kesadaran merek dan citra merek terhadap kesetiaan merek. Peneliti menduga terjadi hubungan sebagai berikut :

- H1. Kesadaran merek mempunyai pengaruh positif terhadap pembentukan kesetiaan merek penguna aplikasi Line Today di Kampus Kalbis Institut.

- H2. Citra merek mempunyai pengaruh positif terhadap pembentukan kesetiaan merek penguna aplikasi Line Today di Kampus Kalbis Institut.

- H1 dan H2. Kesadaran merek dan kesetiaan merek secara simultan atau secara bersamasama mempunyai pengaruh positif terhadap pembentukan kesetiaan merek penguna aplikasi Line Today di Kampus Kalbis Institut.

\section{Unit Analisa dan Sampel}

Penelitian ini menggunakan metode kuantitatif, yaitu yang menurut Sugiyono, (2012:23) dikatakan metode kuantitatif karena data penelitian berupa angka-angka dan analisis menggunakan statistik. Dalam penelitian kuantitatif menekankan pada pengujian teori-teori melalui pengukuran variabel-variabel penelitian dengan angka dan melakukan analisis data dengan prosedur statistik (Indriantoro, 2012:12). Penelitian ini dilakukan pada mahasiswa/i kampus Kalbis Institut Jakarta. Jl. Pulomas Selatan Kav. 22 Jakarta Timur. Oleh sebab itu peneliti mengadakan penelitian dengan menyebar kuesioner di tempat tersebut dengan waktu pengambilan sampel dilakukan selama bulan April - Juni 2017. Sumber data yang digunakan dalam penelitian ini adalah sumber data primer dan sumber data sekunder. Metode pengumpulan data dalam penelitian ini menggunakan dua metode yaitu melalui studi lapangan dan studi kepustakaan.

Menurut Sunyoto (2011:18) Penelitian yang mengunakan sampel, terutama pengikutsertaan orang sebagai responden. Karena disini sampel adalah bagian yang diambil dari suatu populasi yang karateristiknya diteliti dan dianggap dapat mewakili populasi secara keseluruhan. Untuk menentukan berapa banyak sampel peneliti mengunakan rumus slovin: dengan jumlah populasi 2622 yang merupakan mahasiwa/i Kalbis Institut secara keseluruhan.

Sampel adalah bagian dari jumlah dan karakteristik yang dimiliki oleh populasi tersebut (Sugiyono, 2015:168). Dalam penelitian ini teknik penentuan jumlah sampel yang peneliti gunakan Menurut Sunyoto (2011:21) penentuan jumlah sampel dapat dilakukan dengan menggunakan rumus Slovin dengan keterangan sebagai berikut : 
INOBIS: Jurnal Inovasi Bisnis dan Manajemen Indonesia

Volume 1, Nomor 2, Maret 2018

Yonatan Widiyanto, Febriansyah

$\mathrm{n}=\frac{N}{1+\left(N x \propto^{2}\right)}$

Keterangan

$\mathrm{n}$ : Jumalh sampel

$\mathrm{N}$ : Populasi ( 2622)

$\alpha$ : Taraf signifikasi 0,05

Sehingga jumlah sampel minimum yang digunakan dalam $\mathrm{p}$ untuk menjadi responden penelitian ini adalah

$$
\begin{aligned}
& \mathrm{n}=\frac{N}{1+\left(N x \alpha^{2}\right)} \\
& \mathrm{n}=\frac{2622}{1+\left(2622 \times 0,05^{2}\right)}=\frac{2622}{1+(2622 \times 0,0025)} \\
& \mathrm{n}=\frac{2622}{1+6,555}=\frac{2622}{7,555}=347 \text { Sampel }
\end{aligned}
$$

Pendekatan umum yang digunakan dalam penelitian ini adalah nonprobality sampling, dimana elemen populasi dipilih atas dasar availabilitasnya atau karena pertimbangan pribadi peneliti bahwa mereka dapat mewakili populasi. Metode pengambilan sampel yang digunakan dalam penelitian ini adalah convenienve sampling yaitu dimana para peneliti lapangan memiliki kebebasan untuk memilih siapa saja yang mereka temui (Sunyoto, 2011:65).

\section{Uji Pre Test dan main test}

Dalam penelitian, data mempunyai kedudukan yang paling tinggi, karena data merupakan penggambaran variabel yang diteliti dan berfungsi sebagai alat pembuktian hipotesis. Benar tidaknya data, sangat menentukan bermutu tidaknya hasil penelitian. Sedang benar tidaknya data, tergantung dari baik tidaknya instrumen pengumpulan data. Pengujian instumen biasanya terdiri dari uji validitas dan reliabilitas.

Validasi adalah suatu ukuran yang menunjukan tingkat-tingkat kevalidan atau kesahihan suatu instrumen. Suatu instrumen yang valid atau sahih mempunyai validasi yang tinggi. Sebaliknya, instrumen yang kurang valid berarti memiliki validitas rendah. Sebuah instrumen dikatakan valid apabila dapat mengungkap data dari validasi yang diteliti secara tepat (Sunyoto,2011:69)

Realibilitas menunjukan pada suatu pengertian bahwa sesuatu instrumen cukup dapat dipercaya untuk digunakan sebagai alat pengumpul data karena instrumen tersebut sudah baik (sunyoto, 2011:70). Menurut sunyoto (2011:131) Model regresi linier berganda dapat disebut baik jika terbatas dari asumsi-asumsi klasik statistik, yaitu normalitas,multikolinieritas,Heteroskedasstistias. Menurut santoso (2012) Data berdistribusi normal jika kurva normal ada digrafing dan mengikuti bentuk bel (lonceng). Dari grafik seberapa data mempunyai kurva yang berbentuk lonceng. Karena itu eror model regresi dapat dikatakan berdistribusi normal.

Untuk menentukan ada tidaknya multikolinieritas dapat digunakan cara lain sebagai berikut : 
INOBIS: Jurnal Inovasi Bisnis dan Manajemen Indonesia

Volume 1, Nomor 2, Maret 2018

Yonatan Widiyanto, Febriansyah

Variabel bebas mengalami multikolinieritas jika : $\alpha$ hitung $<\alpha$ dan VIF hitung $>$ VIF. Variabel bebas tidak mengalami multikolinieritas jika : $\alpha$ hitung $>\alpha$ dan VIF hitung $<$ VIF.

Heteroskedastisitas terjadi jika pada scatterplot titik-titiknya mempunyai pola yang teratur baik menyempit, melebar maupun bergelombang-gelombang.

\section{E. Uji Hipotesis}

Hipotesis merupakkan jawaban sementara terhadap rumusan masalah penelitian, oleh karena itu rumusan masalah penelitian biasanya disusun dalam bentuk pertanyaan (Sugiyono, 2005:51).Adapun hipotesis dalam penelitian ini adalah sebagai berikut

Menurut Sunyoto (2011:145) Analisis Regresi Linier berganda dipakai untuk mengetahui besarnya pengaruh variabel bebas (Kesadaran Merek, Citra Merek) terhadap variabel terikat ( Kesetiaan Merek).

Menurut sunyoto (2011:146) Uji T digunakan untuk mengetahui ada tidaknya hubungan atau pengaruh yang berarti (signifikan) antara variabel independen (Kesadaran merek, Citra merek ) secara parsial terhadap variabel dependen (Kesetiaan Merek)

Menurut sunyoto (2011:147) Uji F dilakukan untuk mengetahui pengaruh antara variabel independen terhadap variabel dependen secara bersama-sama.

Koefisien Determinasi suatu uji untuk mengetahui presentase pengaruh variabel bebas secara serentak terhadap variabel terikat. Koefisien ini menunjukan seberapa besar presentase variasi vareabel bebas yang digunakan dalam model mampu menjelaskan variasi vareabel terikat (Sugiyono,2012:212).

\section{Pembahasan}

\section{A. Hasil Uji Validitas}

Hasil uji validitas, dengan total 347 responden menunjukan hasil bahwa masingmasing variabel KM, CM,dan KSM memiliki hasil valid karena nilai korelasi person lebih besar dari nilai tabel $\mathrm{N}$ yaitu 0,105 .

\section{B. Hasil Uji Reliabilitas}

Hasil uji reliabilitas memberikan hasil bahwa butir-butir pernyataan memiliki hasil reliabel dengan hasil Cronbach Alpha > 0,6.

\section{Uji Asumsi Klasik}

Pada penelitian ini, uji normalitas dilakukan dengan model histogram Hasilnya menunjukkan bahwa model regresi memenuhi asumsi normalitas karena kurva normal ada digrafik dan mengikuti bentuk bel (lonceng).

Model regresi penelitian ini juga tidak terjadi atau memiliki gejala multikolonieritas karena nilai tolerance 0,612 $\geq 0,10$ dan nilai VIF (Variance Inflation Factor) 1,634 $\leq 10$.

Selanjutnya, uji heterokedastisitas dilakukan dengan uji park. Hasilnya menunjukkan gejala heterokedastisitas pada X1 dengan nilai sig $0,14<0,05$. Hasil tidak menunjukan adanya heterokedastisitas pada karena nilai signifikansi variabel X2 dengan nilai 0,495 > 0,05 . 
INOBIS: Jurnal Inovasi Bisnis dan Manajemen Indonesia

Volume 1, Nomor 2, Maret 2018

Yonatan Widiyanto, Febriansyah

\section{Uji Hipotesis}

Uji regresi linier berganda untuk mengetahui besaran pengaruh variabel bebas (X1 dan $\mathrm{X} 2$ ) terhadap variabel terikat $(\mathrm{Y})$. Hasil menunjukan bahwa koefisien regresi variabel $\mathrm{X} 1$ dan $\mathrm{X} 2$ memiliki hubungan dengan dengan variabel $\mathrm{Y}$, kemudian variabel X1 yang memiliki hub lebih besar terhadap variabel $\mathrm{Y}$ dengan konstanta variabel X1 $>\mathrm{X} 2(0,580>0,443)$.

Uji hipotesis $t$ ini bertujuan untuk mengetahui variabel bebas (XI dan X2) terhadap variabel terikat $(\mathrm{Y})$, serta mengetahui pengaruh mana yang lebih besar antara X1 dan X2 terhadap Y. Hasil menunjukan bahwa t hitung $\geq \mathrm{t}$ kritis $=9,045>1,966$ artinya variabel kesadaran merek (X1) berpengaruh secara signifikan terhadap kesetiaan merek (Y). Kemudian dari variabel pada variabel X2 menunjukan bahwa 7,431 >1,966 artinya variabel citra merek (X2) berpengarih signifikan terhadap kesetiaan merek (Y). Diantara variabel bebas, variabe kesadaran merek (X1) yang memiliki hasil yang lebih besar yaitu 9,045.

Uji hipotesis $\mathrm{f}$ ini bertujuan untuk mengetahui apakah variabel kesadaran merek (X1) dan variabel citra merek (X2) secara bersama-sama atau secara simultan mempengaruhi variabel kesetiaan merek $(\mathrm{Y})$ hasil menunjukan bahwa $\mathrm{f}$ hitung $>\mathrm{f}$ kritis $=180,405>3,021$. Hal ini menjelaskan atau mengindikasikan bahwa $\mathrm{H}_{0}$ tidak di terima, yang mengartikan bahwa variabel kesadaran merek (X1) dan citra merek (X2) sebagai variabel independen dengan hasil secara bersamaan memiliki pengaruh yang segnifikat terhadap variable terikat kesetiaan merek (Y).

Analisa koefesien determinasi (R2) digunakan untuk mengetahui seberapa besar presentase pengaruh variabel bebas kesadaran merek (X1) dan citra merek (X2) terhadap kesetiaan merek (Y).Hal ini menunjukan bahwa kesetiaan merek sebesar 0,512 (51,2\%) dijelaskan oleh variabel kesadaran merek dan citra merek, sedangkan $(48,8 \%)$ dijelaskan oleh variabel lain yang tidak dimasukkan kedalam penelitian. Hasil ini menunjukan bahwa $\mathrm{R}^{2}$ mendekati satu, sehingga variabel bebas (kesadaran merek dan citra merek ) secara keseluruhan dapat menjelaksan variabel terikat ( kesetiaan merek).

\section{Simpulan}

Bedasarkan hasil penelitian dan pembahasan yang telah dilakukan dengan sampel 347 responden pada bagian sebelumnya, maka pada bagian ini dapat di peroleh kesimpulan yang telah di uraikan sebagai berikut:

1. Variabel kesadaran merek (X1) berpengaruh secara signifikan terhadap pembentukan kesetiaan merek (Y).

2. Variabel citra merek (X2) berpengaruh secara signifikan terhadap pembentukan kesetiaan merek (Y).

3. Variabel kesadaran merek (X1) memiliki pengaruh lebih besar dibanding dengan variabel citra merek (X2).

4. Variabel kesadaran merek (X1) dan variabel citra merek (X2) secara bersamaan (simultan) memiliki pengaruh signifikan terhadap pembentukan variabel kesetiaan merek (Y). 
INOBIS: Jurnal Inovasi Bisnis dan Manajemen Indonesia

Volume 1, Nomor 2, Maret 2018

Yonatan Widiyanto, Febriansyah

\section{Daftar Pustaka}

\section{Internet}

Andrologi, Febrian. (2014). "Analisa Pengaruh Brand Image dan Brand Awareness terhadap Brand Loyalty dan Dampaknya terhadap Brand Equity”.[Online].Diakses $\begin{array}{llll}\text { Tanggal } & 06 & \text { Januari } & 2017\end{array}$ http://eprints.undip.ac.id/43437/1/01_ANDROLOGI.pdf.

Library.Binus.ac.id.(2014).“eColls/eThesisdoc/bab2.”[Online] Diakses tanggal 13 Maret 2017 darihttp://library.binus.ac.id/eColls/eThesisdoc/Bab2/2014-2-01579-

HM\%20Bab2001.pdf

Pamungkas,Bramaseto Rosie.(2014). "Analisa pengaruh kesadaran merek dan persepsi kualitasterhadap equitas merek melalui loyalitas merek.”.[Online].Diakses Tanggal 16 Juni 2017 dari $\quad$ http://Eprints.undip.ac.id/45269/1/06_pamungkas.pdf.

Pradipta, Dyah Ayu Anisha. (2012). "Pengaruh Citra Merek (Brand Image) Terhadap Loyalitas Konsumen Produk Oli Pelumas PT.Pertamina (Persero)Enduro 4T Di Makassar”.[Online]. Diakses Tanggal 11 Juni 2017 dari http://repository.unhas.ac.id/bitstream/handle/

Survei,Databoks.(2017). "Presentase Sumber Akses Berita Online”.[ Online].Diakses Tanggal 17 Agustus 2017 dari

https://www.google.co.id/search?q=Persentase+pembaca+berita+online+databooks\&rlz

Survei,Data. (2016). " Logo Aplikasi Line”. Diakses 12 Januari 2017 Dari http://www.line.me/id/

Survei,Data. (2017). “ Tamplet Line today”. Diakses tanggal 12 januari 2017darihttps://today.line.me/id/pc?gclid=COGHiILL_NQCFcUYjwodh0UFdw

Survei,Data.(2017).“Jumlah mahasiswa aktif kampus Kalbis Institute”.[Online].Diakses Tanggal 3 Mei 2017 dari http://forlap.dikti.go.id

\section{Buku}

Indriantoro, Nur \& Bambang Supomo. (2012) Metodologi Penelitian Bisnis Untuk Akuntansi Dan manajemen. Yogyakarta: BPFE YOGYAKARTA.

Jonker, Jon Bratjan J.W Pennink dan Sari Wahyuni. ( 2011). " Metodelogi Penelitian panduan untuk master dan Ph.D.di Bidang Manajemen”. Jakarta : Salemba Empat.

Kartajaya,Hermawan.(2010).“ Brand Opration”. Jakarta : Erlangga.

Kolter, Philip Kevin Lane Keller.(2008).“Manajemen Pemasaran”. Jakarta : Erlangga.

Mulyatiningsih, Endang. (2012). Metode Penelitian Terapan Bidang Pendidikan. Bandung: Alfabeta.

Priyanto,Duwi.(2009). "Spss untuk analisa korelasi,regresi, dan multivariate”. Cetakan Pertama. Yogyakarta:Gava Media.

Robbins, Stephen P, \& Coulter Marry.(2010).“Manajemen Edisi Kesepuluh Jilid 1.Jakarta :Erlangga.

Sugiyono. (2014). “Metodelogi penelitian bisnis”.Bandung: Alfabeta CV.

Sugiyono.(2012).“(Metode penelitian kombinasi (Mix Metode). Bandung:Alfabeta.

Sugiyono. (2015). Metode Penelitian Tindakan Komprehensif. Bandung: Alfabeta.

Sunyoto,Danang.(2011).“Metodologi PenelitianEkonomi”.'Yogyakarta : CAPS. 
INOBIS: Jurnal Inovasi Bisnis dan Manajemen Indonesia

Volume 1, Nomor 2, Maret 2018

Yonatan Widiyanto, Febriansyah

Tjipto Fandy, dan Gregorius Chandra. (2012). "Pemasaran Strategik Mengupas Pemasaran strategic,BrandingStrategy, Customer Satisfaction,Strategi Kompetitif hingga eMarketing". Yogyakarta: ANDI.

Wijayanto Dian.(2012). ' Pengantar Manajemen'. Jakarta : Gramedia Pustaka Utama.

\section{Jurnal}

Bastian, Dani Alexander. (2014). “Analisa Pengaruh Citra Merek dan Kepercayaan merek terhadap loyalitas merek Ades PT. Ades Alfindo Putra Setia”. Jurnal manajemen pemasaran petra Vol.2, No. 1, hlm

Saputri,M Eka Dan Tutut Ratna Pranata. (2014). "Pengaruh Brand Image Terhadap kesetiaan penguna smartphone iphone.".Jurnal Sosioteknologi vol.13, No.3. hlm 184 Diakses Tanggal 16 Juni 2017 pukul 13:23 WIB.

Setianegara,Dika, Zakaria Wahab, dan Welly Nailis. ( 2015 ). " Analisa Pengaruh Brand Image dan Brand Awareness Terhadap Brand Equity Obat Herbal Ekstak Kulit Mangis (Mastin”.Jurnal Imiah Manajemen Bisnis Dan Terapan Tahun XXI No.2, hlm 20 Diakses Tanggal 06 Maret 2017 Pukul 17:40 WIB.

Tamaka , Irvandy. (2013). “ Citra Merek,Ekuitas Merek,DanK Kualitas Produk Pengaruhny Terhdap Sikap Konsumen Pada Produk Daihatsu Di PT. Astra International Daihatsu Manado".Jurnal manjemen pemasaran universitas samratulangi manado Vol.1, No.3,hlm 1319 Diakses tanggal 11 Juni 2017 pukul 16:24 WIB.

Tamaka,Irvandy. (2013). “ Citra Merek,Ekuitas Merek,DanK Kualitas Produk Pengaruhnya Terhdap Sikap Konsumen Pada Produk Daihatsu Di PT. Astra International Daihatsu Manado". Jurnal manjemen pemasaran universitas samratulangi manado Vol.1, No.3, hlm 1319 Diakses tanggal 11 Juni 2017 pukul 16:24 WIB.

Sondakh,M.A, Johnny j.S,Sintje A.R. (2017). “ Pengaruh Berita Line Today Terhadap Prilaku Mahasiswa Program Studi Ilmu Sosial dan Ilmu Politik Universitas Sam Ratulangi Manado.” E-Jurnal “ Acta Diurna Vol.No 6, Diakses tanggal 14 Agustus 2017 pukul 22.07 WIB.

\section{Skripsi/Tesis}

Novan, Yonathan (2013). “ Kepuasa Remaja Menggunakan Aplikasi Line (Studi Deskriptif Kuantitatif Kepuasan Remaja Menggunakan Aplikasi LINE di Surabaya )”. Skripsi Sarjana Ilmu Komunikasi Universitas Pembangunan Nasional "Veteran", Surabaya Jawa Timur.

Yogama, Felix, Daru Wibowo.(2014). “ Pengaruh Atribut Stiker Line Terhadap Loyalitas Merek Pengguna Line.” Skripsi Sarjana Ilmu Komunikasi Universitas Bina Nusantara, Jakarta. 